Krystyna Gomótka

Politechnika Gdańska
Studia

Wschodnioeuropejskie

Nr 12/2020

\title{
Ropa i gaz w gospodarce Azerbejdżanu
}

A zerbejdżan to jedno z trzech państw Kaukazu Południowego o powierzchni $86600 \mathrm{~km}^{2}$, zamieszkiwanej przez 9981,5 tys. obywateli ${ }^{85}$.To państwo bogate w surowce naturalne, $\mathrm{z}$ których największą rolę $\mathrm{w}$ wymianie międzynarodowej wiodą czołowe bogactwa mineralne - ropa i gaz. W historii tego państwa to właśnie te surowce odegrały czołową rolę w gospodarce, choć Azerbejdżan posiada inne bogactwa mineralne. Należą do nich: miedź, złoto, srebro, tytan, chrom, mangan, kobalt, molibden, antymon, oraz sól kamienna ${ }^{86}$.

Problem badawczy polega na ukazaniu roli surowców mineralnych - ropy i gazu dla gospodarki Azerbejdżanu.

Celem pracy jest określenie znaczenia ropy i gazu w gospodarce Azerbejdżanu w okresie dwóch pierwszych dekad XXI w.

Hipoteza pracy brzmi: Podstawę gospodarki Azerbejdżanu w dwóch pierwszych dekadach XXI w. tworzyły ropa i gaz.

Celem weryfikacji hipotezy autorka postawiła następujące pytania badawcze:

1/ Jaki był udział przemysłu w tworzeniu PKB Azerbejdżanu?

2/ Jak kształtował się udział przemysłu wydobywczego ropy i gazu w dziale przemysł w latach 2000-2018?.

3/Jaka liczba pracowników była zatrudniona w sektorze wydobycia ropy i gazu ?

4/ Jaki procent produkcji ropy naftowej gazu przeznaczony był do sprzedaży za granicą

5/ Jaki udział w ogólnym eksporcie stanowiła ropa i gaz w latach 2000-2018?

6/Jak kształtowały się inwestycje, w tym inwestycje zagraniczne w przemyśle wydobywczym ropy i gazu w latach 2005-2018.

W pracy wykorzystano metody: ilościowe i metody porównawcze.

Praca powstała na podstawie danych statystycznych udostępnionych przez Azerski Urząd Statystyczny, danych Banku Światowego, oraz literatury głównie w języku angielskim i rosyjskim.

\section{Podstawowe wskaźniki makroekonomiczne Azerbejdżanu}

Od czasu odzyskania niepodległości przez Azerbejdżan przy wykorzystaniu ropy naftowej i gazu starano się rozwiązać wiele problemów gospodarczych i politycznych państwa. Posiadanie tych bogactw mineralnych dało Azerbejdżanowi niezawisłość, umożliwiło

\footnotetext{
${ }^{85}$ Azebaijan in figures 2019 r. https://www.stat.gov.az/source/demoqraphy/?lang=en ( 22.02.2020).

86 Mineral Resources in Azerbaijan , International Geology Review, 2009, s. 82-85, https://www.tandfonline.com/doi/abs/10.1080/00206815909473472?journalCode=tigr20 (22.02.2020).
} 
realizację polityki niezaangażowania, zapewniło rozwój gospodarczy. Podstawowe wskaźniki makroekonomiczne w latach 2000-2018 przedstawia tabela 1.

Tabela 1 . Podstawowe wskaźniki makroekonomiczne Azerbejdżanu w latach 2000-2018.

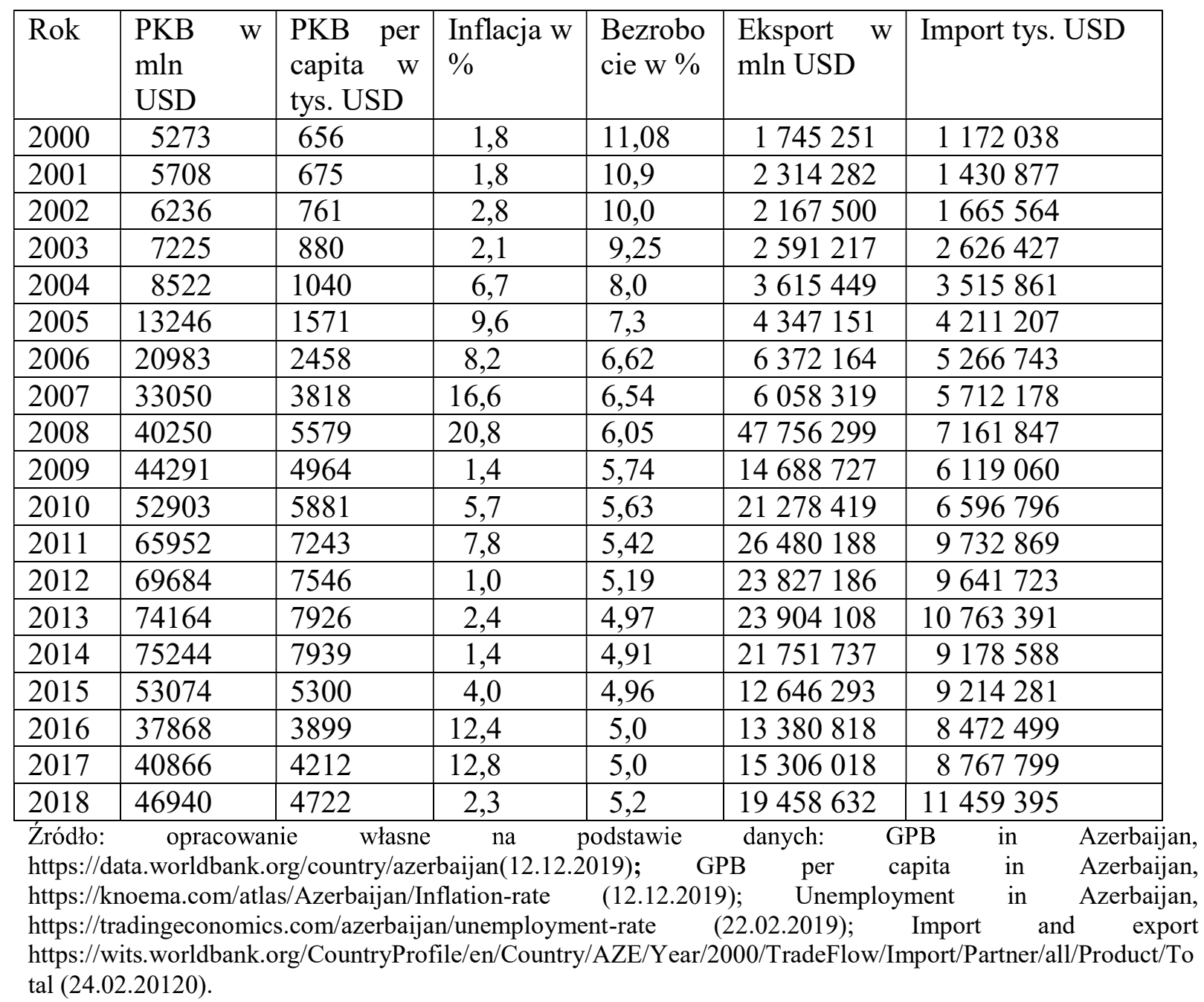

Z danych zamieszczonych w tabeli nr 1 wynika, iż przez cały badany okres $2000-2018$ PKB Azerbejdżanu systematycznie wzrastało, rosło również PKB per Capita. W 2000 r. PKB per capita wyniosło 656 USD a w 2018 r. wzrosło 7 razy i wyniosło 4722 USD. Uzależnienie azerskiej gospodarki od surowców i jej związek z gospodarką światową wiązał się z wzrostem inflacji, która najbardziej uwidoczniała się w latach kryzysu i spadku cen ropy naftowej na rynkach światowych. W badanym okresie systematycznie spadało bezrobocie W Azerbejdżanie, hamowane rozwojem gospodarczym i powstawaniem nowych miejsc pracy. Eksport ropy naftowej i gazu przyczynił się do powstania dodatniego bilansu handlu zagranicznego Azerbejdżanu.

Bogactwo Azerbejdżanu w dużej mierze oparte jest na surowcach mineralnych. W programach rozwoju gospodarczego kluczowe znaczenie mają: przemysł wydobywczy ropy naftowej i gazu ziemnego, metali kolorowych, rozwój infrastruktury transportowej i przemysł 
przetwórczy. Kluczową rolę $\mathrm{w}$ gospodarce odgrywa sektor naftowy ${ }^{87}$. Azerbejdżan jest jednym z najstarszych producentów ropy naftowej na świecie. Początki przemysłu naftowego sięgają pierwszej połowy XIX w i związane są z miastem Baku i półwyspem Absheron. W czasach imperium rosyjskiego $\mathrm{z}$ tego regionu pochodziło 97,7\% rosyjskiej ropy która w 1890 r. stanowiła połowę światowej produkcji ${ }^{88}$. Po odzyskaniu niepodległości Azerbejdżan doświadczył olbrzymiej recesji, spadło wydobycie i sprzedaż ropy spowodowane konfliktem z Armenią o Górski Karabach. Nie bez znaczenia dla rozwoju przemysłu wydobywczego było posługiwanie się przestarzałymi technologiami wydobycia, brak nowych inwestycji oraz mały napływ zagranicznych inwestorów. Dopiero w połowie lat 90 . XX w. udało się tę negatywną tendencję odwrócić. Spowodował to podpisany w 1994 r. kontrakt na wydobycie złóż ropy i gazu w Shah Deniz. W 1996 r. Gruzja i Azerbejdżan podpisały 30 - letnie porozumienie o transporcie azerbejdżańskiej ropy do portu Supsa nad Morzem Czarnym. Umożliwiło to ominięcie terytorium Federacji Rosyjskiej przy dostawach surowca do Europy ${ }^{89}$. Pozostała cześć ropy transportowana jest trzema rurociągami: Baku - Batumi, Baku - Noworosyjsk a od 2006 r. Baku - Tibilisi- Ceyhan.

\section{Udzial przemysłu w tworzeniu PKB, rola przemysłu wydobywczego ropy i gazu oraz}

\section{zatrudnienie.}

W latach 90 -tych XX w. ponad około $70 \%$ PKB Azerbejdżanu pochodziło z przemysłu ropy naftowej i gazu ${ }^{90}$. Po 2000 r. rozwój pól naftowych i gazowych koncentrował się w dwóch projektach - morskim kompleksie złoża Azeri-Chirag-Guneshli i morskim polu naftowym Shah-Deniz ${ }^{91}$. Od połowy lat 90 . XX w rozwijały się nowe gałęzie przemysłu tj.: przetwórczy artykułów spożywczych, odzieżowy, chemiczny, materiałów budowlanych, metalurgiczny, maszyn i urządzeń oraz elektroniczny ${ }^{92}$. Procentowy udział poszczególnych działów gospodarki w tworzeniu PKB w latach 2013-2017 pokazuje tabela 2.

Tabela 2. Procent PKB wytworzony przez poszczególne działy gospodarki narodowej Azerbejdżanu w latach 2013-2017.

\begin{tabular}{|l|c|l|l|l|l|}
\hline Dzial gospodarki & $\mathbf{2 0 1 3}$ & $\mathbf{2 0 1 4}$ & $\mathbf{2 0 1 5}$ & $\mathbf{2 0 1 6}$ & $\mathbf{2 0 1 7}$ \\
\hline Ogółem & 100 & 100 & 100 & 100 & 100 \\
\hline Rolnictwo, leśnictwo, & 5,5 & 5,3 & 6,2 & 5,6 & 5,6 \\
\hline
\end{tabular}

\footnotetext{
${ }^{87}$ Ш Алиев(2017) Проблемы и перспективы организации перерабатывающих отраслей нефти и газа в Азербайджане, РОССИЙСКОЕ ПРЕДПРИНИМАТЕЛЬСТВО, 2017, NR. 5, S.703-710.

${ }_{88}$ A. Ciarreta, S. Nasirov, Analysis of Azerbaijan Oil and Gas Sector, https://www.usaee.org/usaee2011/submissions/OnlineProceedings/Ciarreta_Nasirov-Article1.pdf (25.02. 2020).

${ }^{89}$ Porównaj :UPDATE 1-Azerbaijan plans to resume oil exports via Russia from July 1-SOCAR (Reuters), https://www.reuters.com/article/azerbaijan-oil-russia/update-1-azerbaijan-plans-to-resume-oil-exports-via-russiafrom-july-1-socar-idUSL8N23513C ( 28.02.2020).

${ }^{90}$ Informacja o stosunkach gospodarczych Polski z Azerbejdżanem (2016) Pobrane $10.07 .2016 \quad \mathrm{z}$ http://www.mg.gov.pl/Wspolpraca+z+zagranica/Wspolpraca+gospodarcza+Polski+z+krajami+wschodnimi $+\mathrm{i}+\mathrm{p}$ ozaeuropejskimi/Azerbejdzan.htm ( 1.03.2020).

${ }^{91}$ U.S. Energy Information Administration, 2016; E. Safirowa, The Mineral Industry of Azerbaijan, https://www.usgs.gov/centers/nmic/europe-and-central-eurasia\#aj (3.03.2020)

${ }^{92}$ Г. ЮзбашИеВа, РАЗВИТИЕ ПРОМЫШЛЕННОСТИ В УСЛОВИЯХ ТЕХНОЛОГИЧЕСКИХ СДВИГОВ (НА ПРИМЕРЕ АЗЕРБАЙДЖАНСКОЙ РЕСПУБЛИКИ). Кавказ и глобализация 2014. t. 8, s.75-86.
} 


\begin{tabular}{|l|r|c|c|c|c|}
\hline rybactwo & & & & & \\
\hline Przemysł & $\mathbf{4 5 , 4}$ & $\mathbf{4 1 , 0}$ & $\mathbf{3 2 , 9}$ & $\mathbf{3 7 , 1}$ & $\mathbf{4 0 , 1}$ \\
\hline Produkcja & 4,2 & 4,7 & 4,5 & 4,9 & 4,7 \\
\hline $\begin{array}{l}\text { Produkcja:energii } \\
\text { elektrycznej i pary wodnej }\end{array}$ & 1,9 & 1,8 & 1,4 & 1.3 & 1.0 \\
\hline Zaopatrzenie w wodę & 0,1 & 0,2 & 0,1 & 0,2 & 0,2 \\
\hline Budownictwo & 11,6 & 12,6 & 12,0 & 10,5 & 9.5 \\
\hline Handel i transport & 7.1 & 7.9 & 9,9 & 10.3 & 10,4 \\
\hline Transport i magazynowanie & 4,4 & 4,5 & 6,0 & 6,7 & 6,8 \\
\hline Hotele i restauracje & 1,8 & 2.2. & 2.4 & 2.4 & 2,3 \\
\hline Informacja i komunikacja & 1.7 & 1.8 & 2,0 & 1.8 & 1.6 \\
\hline Usługi & 15,9 & 17,2 & 19,7 & 17,5 & 16,4 \\
\hline Podatki netto & 6,7 & 7,5 & 8,9 & 9.1 & 7.3 \\
\hline
\end{tabular}

Źródło: opracowanie własne na podstawie danych: Structure of GDP by kinds of economic activity (in per cent) Azervbaijan in firgures Baku 2017, s.199.

Z danych zamieszczonych w tabeli 3 wynika, iż przez cały badany okres największą cześć PKB tworzył przemysł w 2013 r. wytwarzał on 45,1 \% a w 2017 r. jego udział spadł do 40,1 \%. Do działów gospodarki narodowej wytwarzających znaczną cześć dochodu Azerbejdżanu w latach 2000-2018 zaliczyć należy budownictwo i usługi. Pozostałe działy gospodarki nie odegrały większego znaczenia $w$ tym procesie. Według danych Azerskiego Urzędu Statystycznego przemysł wydobywczy w latach 2000-2018 miał znaczący udział w przemyśle ogółem. Procent udziału przemysłu wydobywczego w tym przemysłu wydobywczego ropy i gazu ilustruje tabela 3.

Tabela 3. Procent udziału przemysłu wydobywczego $\mathrm{w}$ tym przemysłu wydobywczego ropy $i$ gazu w latach 2000-2018.

\begin{tabular}{|l|l|l|l|l|l|l|}
\hline Rok & $\begin{array}{l}\text { Ogółem } \\
\text { przemy } \\
\text { sł }\end{array}$ & $\begin{array}{l}\text { \% } \\
\text { Przemysł } \\
\text { wydoby } \\
\text { wczy w } \\
\text { ramach } \\
\text { przemysł } \\
\text { u }\end{array}$ & $\begin{array}{l}\text { W tym przemysł } \\
\text { wydobywczy } \\
\text { ropy i gazu }\end{array}$ & $\begin{array}{l}\text { W tym } \\
\text { Wydobycie } \\
\text { rud metali }\end{array}$ & $\begin{array}{l}\text { W tym } \\
\text { kamien, piasek } \\
\text { żwir inne } \\
\text { wydobycie }\end{array}$ & $\begin{array}{l}\text { Usługi dla } \\
\text { przemysłu } \\
\text { wydobywcze } \\
\text { go }\end{array}$ \\
\hline 2000 & 100 & 53,4 & 46,7 & 0,0 & 0,1 & \\
\hline 2001 & 100 & 58,7 & 56,3 & 0,0 & 0,1 & 53,2 \\
\hline 2002 & 100 & 59,5 & 57,0 & 0,0 & 0,2 & 43,6 \\
\hline 2003 & 100 & 56,9 & 53,7 & 0,0 & 0,3 & 42,8 \\
\hline 2004 & 100 & 57,4 & 53,0 & 0,0 & 0,2 & 46,0 \\
\hline 2005 & 100 & 67,0 & 63,8 & 0,0 & 0,3 & 35,9 \\
\hline 2006 & 100 & 72,0 & 69,7 & 0,0 & 0,2 & 30,1 \\
\hline 2007 & 100 & 76,0 & 73,8 & 0,0 & 0,2 & 36,0 \\
\hline 2008 & 100 & 78,0 & 76,7 & 0,01 & 0,2 & 23,09 \\
\hline 2009 & 100 & 77,0 & 74,5 & 0,03 & 0,2 & 25,27 \\
\hline 2010 & 100 & 78,9 & 76,4 & 0,2 & 0,2 & 23,2 \\
\hline 2011 & 100 & 80,5 & 78,0 & 0,2 & 0,2 & 23.4 \\
\hline 2012 & 100 & 78,8 & 76,2 & 0,2 & 0,2 & 29,9 \\
\hline 2013 & 100 & 72,7 & 69,7 & 0,2 & 0,2 & \\
\hline
\end{tabular}




\begin{tabular}{|l|l|l|l|l|l|l|}
\hline 2014 & 100 & 68,5 & 65,3 & 0,2 & 0,2 & 34,3 \\
\hline 2015 & 100 & 62,1 & 55,8 & 0,4 & 0,2 & 43,6 \\
\hline 2016 & 100 & 65,6 & 58,4 & 0,4 & 0,1 & 41,1 \\
\hline 2017 & 100 & 79,3 & 61,1 & 0,7 & 0,1 & 38,1 \\
\hline 2018 & 100 & 73,3 & 65,9 & 0,5 & 0,1 & 33,5 \\
\hline
\end{tabular}

Źródło: opracowanie własne na podstawie : Sənayedə muzdla işləyənlərin orta illik sayı (iqtisadi fəaliyyət və mülkiyyət növləri üzrə), min nəfər ,https://www.stat.gov.az/source/industry/ (22.03.2020)

$\mathrm{Z}$ danych zamieszczonych $\mathrm{w}$ tabeli 3 wynika, iż rola przemysłu wydobywczego $\mathrm{w}$ ramach sektora przemysłu była dominująca. W 2000 r. udział przemysłu wydobywczego wyniósł 46,7 \% a 2018 r. był o 19,2 punktu procentowego wyższy niż w roku rozpoczynającym badanie. Na kolejnej pozycji znalazły się usługi w przemyśle wydobywczym, ale ich znaczenie $\mathrm{w}$ badanym okresie spadało. Wydobycie pozostałych bogactw mineralnych $\mathrm{w}$ porównaniu $\mathrm{z}$ ropą i gazem nie odgrywało większej roli w przemyśle wydobywczym Azerbejdżanu.

Przez cały badany okres w przemyśle zatrudnionych było około $50 \%$ wszystkich pracujących w Azerbejdżanie ${ }^{93}$. Liczbę pracowników przemysłu pracowników zatrudnionych w przemyśle wydobywczym oraz przemyśle wydobywczym w sektorze ropy i gazu przedstawia tabela 4 .

Tabela 4. Liczba pracowników zatrudnionych w przemyśle, przemyśle wydobywczym oraz w sektorze wydobycia ropy i gazu w tys.

\begin{tabular}{|l|l|l|l|}
\hline Rok & $\begin{array}{c}\text { Ogółem zatrudnionych } \mathrm{w} \\
\text { tys. w przemyśle }\end{array}$ & $\begin{array}{c}\text { Zatrudnionych w } \\
\text { sektorze wydobywczym } \\
\text { w tys. }\end{array}$ & $\begin{array}{c}\text { Zatrudnionych w } \\
\text { sektorze wydobycia } \\
\text { ropy i gazu w tys. }\end{array}$ \\
\hline 2000 & 200,2 & 33,7 & 16,7 \\
\hline 2001 & 185,9 & 35,6 & 20,2 \\
\hline 2002 & 176,9 & 34,9 & 23,2 \\
\hline 2003 & 170,9 & 38,6 & 24,9 \\
\hline 2004 & 175,3 & 39,6 & 25,8 \\
\hline 2005 & 193,2 & 40,8 & 26,8 \\
\hline 2006 & 197,0 & 41,5 & 29,5 \\
\hline 2007 & 208,4 & 41,1 & 28,3 \\
\hline 2008 & 210,3 & 40,3 & 28,2 \\
\hline 2009 & 192,3 & 37,0 & 25,9 \\
\hline 2010 & 181,8 & 36,6 & 24,7 \\
\hline 2011 & 176,7 & 35,6 & 23,5 \\
\hline 2012 & 181,0 & 36,8 & 24,0 \\
\hline 2013 & 197,2 & 39,7 & 23,2 \\
\hline 2014 & 197,2 & 36,7 & 22,4 \\
\hline 2015 & 187,1 & 34,9 & 21,8 \\
\hline 2016 & 186,1 & 34,1 & 21,4 \\
\hline 2017 & 197,1 & 33,8 & 21,2 \\
\hline
\end{tabular}

93 A. Ciarreta, S. Nasirov, Analysis of Azerbaijan Oil and Gas Sector, https://www.usaee.org/usaee2011/submissions/OnlineProceedings/Ciarreta_Nasirov-Article1.pdf( 28.03.2020) 


\begin{tabular}{|l|l|l|l|}
\hline 2018 & 210,7 & 33,9 & 23,4 \\
\hline Źódlo: opracowal number of employees in
\end{tabular}

Źródło: opracowanie własne na podstawie The average annual number of employees in the industry (by kinds of activity and property forms), thousand persons, https://www.stat.gov.az/source/industry/?lang=en ( 28.03.2020).

Z danych zamieszczonych w tabeli 4 wynika, iż 2000 r. w osoby zatrudnione w sektorze wydobywczym stanowiły 16,8\% wszystkich osób zatrudnionych w dziale przemysłu a zatrudnione w sektorze wydobycia ropy i gazu 8,34 \% wszystkich zatrudnionych w przemyśle Pracownicy zatrudnieni w sektorze wydobycia ropy i gazu stanowili 49,55 \% wszystkich zatrudnionych w przemyśle wydobywczym. W ostatnim roku badania 2018 - pracownicy sektora wydobywczego stanowili 16,08 \% sektora przemysłu a pracownicy zatrudnieni w sektorze wydobycia ropy i gazu 10,78 \% sektora przemysłu. Wydobywający ropę i gaz stanowili $69 \%$ pracowników sektora przemysłu wydobywczego. Zatrudnienie w sektorze wydobywczym znacznie spadło w drugiej dekadzie XXI w porównaniu z zatrudnieniem $\mathrm{z}$ lat 90. $\mathrm{XX} \mathrm{w}^{94}$.

\section{Eksport i inwestycje}

Azerbejdżan w latach 2000-2018 nie należał do czołowych producentów ropy i gazu ${ }^{95}$. Podaż ropy i gazu znacznie przewyższała zapotrzebowanie na te produkty obywateli Azerbejdżanu, dlatego znaczną część wydobytych surowców sprzedawano na rynkach zagranicznych. Produkcję i sprzedaż ropy naftowej w tys. ton oraz produkcję i sprzedaż gazu w tys. $\mathrm{m}^{3}$. przedstawia tabela 5 .

Tabela 5. Produkcja i sprzedaż ropy naftowej w tys. ton oraz produkcja i sprzedaż gazu w tys. $\mathbf{m}^{3}$.*

\begin{tabular}{|l|l|l|l|l|}
\hline Rok & $\begin{array}{l}\text { wydobycie } \\
\text { ropy naftowej } \\
\text { w tys. ton }\end{array}$ & $\begin{array}{l}\text { Sprzedaż ropy } \\
\text { naftowej w tys. ton }\end{array}$ & $\begin{array}{l}\text { Wydobycie gazu w } \\
\mathrm{m}^{3}\end{array}$ & $\begin{array}{l}\text { Sprzedaż gazu m } \\
3\end{array}$ \\
\hline 2000 & 14017 & - & - & - \\
\hline 2001 & 14909 & - & - & - \\
\hline 2002 & 15334 & - & - & - \\
\hline 2003 & 15381 & - & - & - \\
\hline 2004 & 15549 & - & - & - \\
\hline 2005 & 22214 & - & 5.700 & - \\
\hline 2006 & 32268 & 32200 & 9,100 & 6,100 \\
\hline 2007 & 42598 & 42500 & 16,800 & 10,800 \\
\hline 2008 & 44514 & 44400 & 23,400 & 16.300 \\
\hline 2009 & 50416 & 50400 & 23,600 & 16,300 \\
\hline 2010 & 50838 & 50700 & 26,300 & 16,700 \\
\hline
\end{tabular}

\footnotetext{
${ }^{94}$ 3rd National Report on the implementation of the European Social Charter (revised) submitted by Goverment of Azerbaijan Report registered by the Secretariat on 10 November 2009 CYCLE 2010, https://rm.coe.int/CoERMPublicCommonSearchServices/DisplayDCTMContent?documentId=090000168048ac 869 1.04.2020)

${ }^{95}$ Ukazują to dane za lata 2002-2018 zawarte w materiałach: Oil extraction (including gas condensate) by countries of world, https://www.stat.gov.az/source/industry/?lang=en (4.04.2020)
} 


\begin{tabular}{|l|l|l|l|l|}
\hline 2011 & 45626 & 45400 & 25,700 & 16,700 \\
\hline 2012 & 43375 & 43000 & 26,800 & 17,200 \\
\hline 2013 & 43457 & 43200 & 29,200 & 17,900 \\
\hline 2014 & 42076 & 42000 & 29,600 & 18,800 \\
\hline 2015 & 41628 & 41600 & 29,200 & 19,200 \\
\hline 2016 & 41050 & 41000 & 29,300 & 18,700 \\
\hline 2017 & 38688 & 38600 & 28,600 & 18,200 \\
\hline 2018 & 38814 & 38700 & 30,500 & 19,200 \\
\hline
\end{tabular}

*Dane dotyczące sprzedaży ropy i gazu dostępne są od $2005 \mathrm{r}$.

Źródło: opracowanie własne na podstawie : Azərbaycanda neft hasilatı (qaz kondensatı daxil olmaqla), min ton, https://www.stat.gov.az/source/industry/ (4.04.2020)

$\mathrm{Z}$ danych zamieszczonych $\mathrm{w}$ tabeli 5 wynika, iż prawie cała wydobyta ropa naftowa była sprzedawana. Wzrastające zapotrzebowanie na ten surowiec na rynkach światowych spowodowało wzrost wydobycia i sprzedaży ropy. Zarówno w 2000 r. jak w 2018 r. Azerbejdżan sprzedał na rynek zagraniczny prawie $99 \%$ wydobywanej ropy. Inaczej kształtowała się sytuacja na rynku gazu. W tym przypadku Azerbejdżan w 2000 r. sprzedał $67 \%$ a w 2018 r. $62 \%$ wydobywanego gazu. Udział eksportu ropy naftowej i gazu w ogólnym eksporcie w latach 2000-2018 przedstawia tabela 7.

Tabela 7. Udzial w ogólnym eksporcie ropy i gazu w latach 2000-2018 w tys. USD.

\begin{tabular}{|l|l|l|}
\hline Rok & Eksport ogółem w tys. USD & Eksport ropy naftowej i gazu w tys. USD \\
\hline 2000 & 1745251 & 1484903,8 \\
\hline 2001 & 2314282 & 2113594,5 \\
\hline 2002 & 2167500 & 1927359,1 \\
\hline 2003 & 2591217 & 2227710,7 \\
\hline 2004 & 3615449 & 2972424,6 \\
\hline 2005 & 4347151 & 3337035,1 \\
\hline 2006 & 6372164 & 5390285,9 \\
\hline 2007 & 6058319 & 4931210,5 \\
\hline 2008 & 47756299 & 46369543,5 \\
\hline 2009 & 14688727 & 13644201,8 \\
\hline 2010 & 21278419 & 20119943,9 \\
\hline 2011 & 26480188 & 25112498,4 \\
\hline 2012 & 23827186 & 22281145,2 \\
\hline 2013 & 23904108 & 22255821,0 \\
\hline 2014 & 21751737 & 20193531,9 \\
\hline 2015 & 12646293 & 11203446,6 \\
\hline 2016 & 13380818 & 12301219,8 \\
\hline 2017 & 15306018 & 13911994,5 \\
\hline 2018 & 19458632 & 17920300,0 \\
\hline Opracowanie wlasne na podstawie: Struktura towarowa eksportu w tys. USD w latach 1992-2018, \\
https://www.stat.gov.az/source/industry/(4.04.2020)
\end{tabular}


Eksport ropy naftowej i gazu to poważne źródło dochodów Azerbejdżanu ${ }^{96}$. Potwierdzają to dane zamieszczone $\mathrm{w}$ tablicy 7 . Dochody państwa eksportu ropy naftowej w $2000 \mathrm{r}$. stanowiły $85 \%$ wartości całego eksportu. W 2018 r. wzrosły one do $92 \%$ wartości całego eksportu. Wielkość dochodu z eksportu ropy naftowej i gazu wskazuje na silną zależność eksportu od cen minerałów na rynku światowym. Ujawnia również iż Azerbejdżan w latach 2000-2018 nie miał innych towarów, które zastąpiłyby eksport ropy i gazu ${ }^{97}$.

Czołowymi importerami tych cennych minerałów - ropy i gazu w latach 2000-2018 były Rosja, Turcja, Chiny, Niemcy, Ukraina ${ }^{98}$. Ciągłość eksportu ropy i gazu zapewniały nie tylko zwiększające się wydobycie lecz innowacyjne inwestycje w przemysł Azerbejdżanu. Wielkość inwestycji $\mathrm{w}$ manatach $\mathrm{w}$ przemysł, w tym przemysł wydobywczy ropy i gazu $\mathrm{w}$ latach 2005-2018 r. przedstawia Tabela 8.

\section{Tabela 8. Inwestycje w przemyśle w tym przemyśle wydobycia ropy i gazu w latach 2005-2018 w mln manatów.}

\begin{tabular}{|l|l|l|l|l|l|}
\hline Rok & $\begin{array}{l}\text { Inwestycje } \mathrm{w} \\
\text { cały } \\
\text { przemysł }\end{array}$ & $\begin{array}{l}\text { Inwestycje } \\
\text { przemysł } \\
\text { wydobywczy }\end{array}$ & $\begin{array}{l}\text { Inwestycje } \\
\text { przemysł } \\
\text { wydobywczy ropy } \\
\text { i gazu }\end{array}$ & $\begin{array}{l}\text { Inwestycje } \\
\text { zagraniczne } \\
\text { przemysł } \\
\text { wydobywczy } \\
\text { ropy i gazu }\end{array}$ & $\begin{array}{l}\text { Inwestycje } \\
\text { Krajowe } \\
\text { przemysł } \\
\text { wydobywczy } \\
\text { ropy i gazu }\end{array}$ \\
\hline 2005 & 4176,0 & 3730,0 & 3606,0 & 3210,0 & 396,0 \\
\hline 2006 & 4297,0 & 3386,0 & 3255,0 & 2787,0 & 467,9 \\
\hline 2007 & 4591,0 & 3498,0 & 3470,0 & 2573,0 & 897,1 \\
\hline 2008 & 4249,1 & 2883,0 & 2825,0 & 1908,0 & 916,0 \\
\hline 2009 & 3225,0 & 2080,0 & 1960,0 & 1215,0 & 744,6 \\
\hline 2010 & 4276,0 & 2952,0 & 2933,0 & 1881,0 & 1052,0 \\
\hline 2011 & 5370,0 & 3244,0 & 3022,0 & 1894,0 & 1128,0 \\
\hline 2012 & 6040,0 & 3857,0 & 3822,0 & 2493,0 & 1329,0 \\
\hline 2013 & 7499,6 & 5095,2 & 5069,0 & 3866,2 & 1202,8 \\
\hline 2014 & 7639,5 & 5947,9 & 5926,3 & 4184,6 & 1741,7 \\
\hline 2015 & 8499,9 & 7145,1 & 7120.9 & 5514,3 & 1606,6 \\
\hline 2016 & 9949,8 & 8576,7 & 8559,7 & 6805,0 & 1754,7 \\
\hline 2017 & 10610,1 & 8428,9 & 8400,1 & 6288,9 & 2111,2 \\
\hline 2018 & 8497,2 & 5702,3 & 5672,5 & 3498,7 & 2173,8 \\
\hline
\end{tabular}

Źródło: opracowanie własne na podstawie: Sənayedə əsas kapitala yönəldilən investisiyalar (faktiki qiymətlərlə), milyon manat, https://www.stat.gov.az/source/industry/( 10.04.2020).

96 A. Ciarreta and S. Nasirov, Analysis of Azerbaijan Oil and Gas Sector, https://www.usaee.org/usaee2011/submissions/OnlineProceedings/Ciarreta_Nasirov-Article1.pdf (28.0.3.2020) O. Nuri Aras, E. Suleymanov, R. Husejnow, The importance od the Azerbaijan s Energy Revenues in its Exports Volume and the Effects on the National Economy, International Journal of Business and Social Science 2013, vo. 4 no 6.s. 79-84.

${ }^{97}$ M. Antidze, N. Bagirova , Azerbaijan targets petrochemicals in push to reduce reliance on oil and gas, https:/www.reuters.com/article/azerbaijan-petrochemicals/azerbaijan-targets-petrochemicals-in-push-to-reducereliance-on-oil-and-gas-idUSL8N25249J (6.04.2020)

${ }^{98}$ Azerbaijan, export, partners https://oec.world/en/profile/country/aze/( 7.04.2020). 
Z danych zamieszczonych w tabeli 8 wynika, iż inwestycje w przemysł Azerbejdżanu rosły z roku na rok. Największą wartość osiągnęły w 2017 r. Czołowym sektorem zainteresowania inwestorów był sektor wydobywczy. W 2005 r. inwestycje w ten sektor stanowiły 89,3\% a w 2018 r. spadły do $67,1 \%$ ogółu wszystkich inwestycji. W ramach przemysłu wydobywczego najwięcej inwestycji trafiało do sektora ropy i gazu. W 2005 r. inwestycje w tę gałęź przemysłu stanowiły 96,6 \% a w 2018 r. aż 99,4\% ogółu inwestycji w przemyśle wydobywczym Azerbejdżanu. Oznacza to inwestorzy brak zainteresowania innymi działami gospodarki, przynoszącymi mniejsze zyski.

W latach 90. XX w. w przemyśle wydobywczym Azerbejdżanu w tym ropy i gazu dominowały inwestycje zagraniczne, głównie rosyjskie. Inwestycje krajowe były nieliczne ze względu na przestrzale technologie. Tendencja ta utrzymała się również w dwóch pierwszych dekadach XXI w ${ }^{99}$. W 2005 r. inwestycje zagraniczne stanowiły $89 \%$ a krajowe zaledwie 11 \%. Jednakże władze Azerbejdżanu podejmowały działania, które doprowadziły do wzrostu inwestycji krajowych ${ }^{100}$. W 2018 r. procentowy udział inwestycji zagranicznych w przemyśle wydobywczym ropy i gazu wyniósł $61,6 \%$ co oznacza spadek inwestycji zagranicznych o 27 , $4 \%$. Inwestycje krajowe wzrosły z $11 \%$ w 2005 r. do 38,4 \% czyli o 27,4 \% . Czołowymi inwestorami w Azerbejdżanie pozostają: Wielka Brytania, Turcja, Iran Cypr, Norwegia ${ }^{101}$

\section{Zakończenie}

Wydobycie i eksport ropy naftowej i gazu od XIX w są podstawą gospodarki Azerbejdżanu. Ropa naftowa i gaz po rozpadzie i odzyskaniu niepodległości Azerbejdżanu tworzyły dochód narodowy w ponad $70 \%$. Wraz z rozwojem innych gałęzi przemysłu oraz sektora usług w latach 90. XX w spadł udział przemysłu w tworzeniu PKB i w 2013 r. wyniósł 45, 4\% a w 2017 40,1 \%. Wzrastała rola przemysłu wydobywczego którego udział w dziale przemysł w 2000 r. wyniósł 53,4 \% a w 2018 r. - 73,3\%. Dominujące znaczenie miało wydobycie ropy i gazu, które stanowiło w 2000 r. stanowiło 46,7 a w 2018 r. - 65,7 \% przemysłu wydobywczego. Światowe zapotrzebowanie na ropę i gaz wymusiło zwiększenie zatrudnienia w tym sektorze z 167000 w 2000 r. do 234000 pracowników w 2018 r. Prawie cala produkcja ropy naftowej kierowana była do sprzedaży. W latach 2000-2018 sprzedano za granicę 99\% wydobytego surowca. W nieco mniejszym stopniu sprzedawany był gaz. Dochody ze sprzedaży ropy i gazu stanowiły w 2000 r. $85 \%$ a w 2020 - $92 \%$ kwoty całego eksportu Azerbejdżanu. Jej wielkość dowodzi dużego zapotrzebowania na ropę naftową i gaz a $\mathrm{z}$ drugiej pokazuje kruchość gospodarki Azerbejdżanu opartej na jednym filarze. Wydobycie ropy i gazu oraz sprzedaż były w dużej mierze możliwe dzięki inwestycjom zagranicznym. Inwestorzy głównie z Wielkiej Brytanii, Turcji, Iranu Cypru i Norwegii w

\footnotetext{
${ }^{99}$ A. Mehlijew, Foreign direct Investment in Azerbaijan Economy : Current Status, development trends and challenges, https://bakuresearchinstitute.org/foreign-direct-investment-in-azerbaijans-economy-current-statusdevelopment-trends-and-challenges/( 12.04.2020).

100 Azerbaijan Linking Domestic Suppliers with Foreign Investors, https://www.oecd.org/eurasia/competitiveness-programme/eastern-partners/Azerbaijan-Linking-Domestic-

Suppliers-with-Foreign-Investors.pdf ( 13.04.2020)

1012019 Investment Climate Statements: Azerbaijan, https://www.state.gov/reports/2019-investment-climatestatements/azerbaijan/( 2.22.03.2020)
} 
2005 r. zainwestowali 96,6 \% a w 2018 r. aż 99,4\% środków w przemyśle wydobywczym ropy i gazu Azerbejdżanu ${ }^{102}$. Nie byli oni w tym okresie czasu zainteresowani mniej zyskownymi przedsięwzięciami.

\section{Streszczenie}

Gospodarka Azerbejdżanu opiera się na wydobyciu i sprzedaży ropy naftowej i gazu. Duża rola tych surowców w rozwoju gospodarczym widoczna już od XIX w. Problem badawczy polega na ukazaniu roli surowców mineralnych ropy i gazu w gospodarce Azerbejdżanu w dwóch pierwszych dekadach XXI w. W pracy zastosowano metody badawcze: ilościowe i porównawcze. Przeprowadzona analiza potwierdziła, iż podobnie jak w wcześniejszych okresach przemysł wydobywczy a zwłaszcza przemysłu wydobywczy ropy i gazu stanowi podstawę tej gospodarki. Tworzył on w 2017 r. w ponad $40 \%$ PKB. Przemysł wydobywczy w 2000 r. stanowił 53,4\% a w 2018 r. - 73,3 \% działu przemysł. Najważniejszą rolę odgrywała gałąź wydobycia ropy i gazu która 2000 r. stanowiła 46,7 a w 2018 r. - 65,7 \% przemysłu wydobywczego. Ponad $99 \%$ inwestycji zagranicznych lokowane było w sektorze gazu i ropy. Sprzedaż cennych surowców przynosiła Azerbejdżanowi w 2000 r. 85 \% a w 2020 - $92 \%$ wartości całego eksportu.

\section{Słowa kluczowe:}

Ropa naftowa, gaz, gospodarka, PKB, eksport, import

\section{Key words:}

oil, gas, economy, GPB, export, import

\section{Bibliografia:}

1. Алиев Ш., Проблемы и перспективы организации перерабатывающих отраслей нефти и газа в Азербайджане, РОССИЙСКОЕ ПРЕДПРИНИМАТЕЛЬСТВО, 2017, NR. 5, S.703-710.

2. Azerbaijan, export, partners https://oec.world/en/profile/country/aze/( 7.04.2020).

3. Azerbaijan Linking Domestic Suppliers with Foreign Investors, https://www.oecd.org/eurasia/competitiveness-programme/easternpartners/Azerbaijan-Linking-Domestic-Suppliers-with-Foreign-Investors.pdf (13.04.2020).

4. Antidze M., Bagirova N., Azerbaijan targets petrochemicals in push to reduce reliance on oil and gas, https://www.reuters.com/article/azerbaijanpetrochemicals/azerbaijan-targets-petrochemicals-in-push-to-reduce-reliance-on-oiland-gas-idUSL8N25249J ( 6.04.2020).

\footnotetext{
${ }^{102}$ Foreign direct in Azerbaijan, https://www.ceicdata.com/en/azerbaijan/foreign-investment ( 15.04.2020).
} 
5. Azərbaycanda neft hasilat1 (qaz kondensat1 daxil olmaqla), min ton, https://www.stat.gov.az/source/industry/ (4.04.2020).

6. Aras O. N, Suleymanov E., Husejnow R., The importance od the Azerbaijan s Energy Revenues in its Exports Volume and the Effects on the National Economy, International Journal of Business and Social Science 2013, vol. 4 no 6.s. 79-84.

7. Azebaijan in figures 2019 r. https://www.stat.gov.az/source/demoqraphy/?lang=en ( 22.02.2020).

8. Ciarreta A. Nasirov S., Analysis of Azerbaijan Oil and Gas Sector, https://www.usaee.org/usaee2011/submissions/OnlineProceedings/Ciarreta_NasirovArticle1.pdf (25.02. 2020).

9. Foreign direct in Azerbaijan, https://www.ceicdata.com/en/azerbaijan/foreigninvestment ( 15.04.2020).

10. GPB in Azerbaijan, https://data.worldbank.org/country/azerbaijan (12.12.2019)

11. 2019 Investment Climate Statements: Azerbaijan, https://www.state.gov/reports/2019investment-climate-statements/azerbaijan/( 2.22.03.2020).

12. Import and export https://wits.worldbank.org/CountryProfile/en/Country/AZE/Year/2000/TradeFlow/Im port/Partner/all/Product/Total( 24.02.2020).

13. Informacja o stosunkach gospodarczych Polski z Azerbejdżanem (2016) Pobrane 10.07.2016 http://www.mg.gov.pl/Wspolpraca+z+zagranica/Wspolpraca+gospodarcza+Polski+z+ krajami+wschodnimi+i+pozaeuropejskimi/Azerbejdzan.htm (1.03.2020).

14. Юзбашиева Г., РАЗВИТИЕ ПРОМЫШЛЕННОСТИ В УСЛОВИЯХ ТЕХНОЛОГИЧЕСКИХ СДВИГОВ (НА ПРИМЕРЕ АЗЕРБАЙДЖАНСКОЙ РЕСПУБЛИКИ). Кавказ и глобализация 2014. t. 8, s.75-86.

15. Mineral Resources in Azerbaijan , International Geology Review, 2009, s. 82-85, https://www.tandfonline.com/doi/abs/10.1080/00206815909473472?journalCode=tigr 20 (22.02.2020).

16. Mehlijew A., Foreign direct Investment in Azerbaijan Economy : Current Status , development trends and challenges, https://bakuresearchinstitute.org/foreign-directinvestment-in-azerbaijans-economy-current-status-development-trends-andchallenges/( 12.04.2020).

17. Oil extraction (including gas condensate) by countries of world, https://www.stat.gov.az/source/industry/?lang=en (4.04.2020).

18. Sənayedə muzdla işləyənlərin orta illik sayı (iqtisadi fəaliyyət və mülkiyyət növləri üzrə), min nəfər $\quad$ https://www.stat.gov.az/source/industry/ (22.03.2020).

19. Sənayedə əsas kapitala yönəldilən investisiyalar (faktiki qiymətlərlə), milyon manathttps://www.stat.gov.az/source/industry/( 10.04.2020)

20. 3rd National Report on the implementation of the European Social Charter (revised) submitted by Goverment of Azerbaijan Report registered by the Secretariat on 10 November 2009 CYCLE 2010, https://rm.coe.int/CoERMPublicCommonSearchServices/DisplayDCTMContent?docu mentId=090000168048ac86 9 1.04.2020). 
21. Struktura towarowa eksportu w tys. USD w latach 1992-2018, https://www.stat.gov.az/source/industry/( 4.04.2020).

22. The average annual number of employees in the industry (by kinds of activity and property forms), thousand persons, https://www.stat.gov.az/source/industry/?lang=en ( 28.03.2020).

23. Unemployment

in

Azerbaijan, https://tradingeconomics.com/azerbaijan/unemployment-rate (22.02.2019)

24. UPDATE 1-Azerbaijan plans to resume oil exports via Russia from July 1-SOCAR (Reuters), https://www.reuters.com/article/azerbaijan-oil-russia/update-1-azerbaijanplans-to-resume-oil-exports-via-russia-from-july-1-socar-idUSL8N23513C (28.02.2020).

25. U.S. Energy Information Administration, 2016; E. Safirowa, The Mineral Industry of Azerbaijan, https://www.usgs.gov/centers/nmic/europe-and-central-eurasia\#aj (3.03.2020) 